\title{
VALLANIMEDE KÜSIMUS 1930. AASTATE VALLAREFORMIS
}

\author{
TAAVI PAE, MADLI-JOHANNA MAIDLA, ERKI TAMMIKSAAR
}

I

seseisvunud Eesti Vabariigis alustati üsna pea nimede eestistamisega. Eelkõige puudutas see perekonnanimesid, vähemal määral ka eesnimesid ja toponüüme. Juba 1921. aastal anti välja koguteos ja juhised inimeste nimede eestistamiseks (Eestlasele... 1921). Siiski ei saavutanud nimemuutmised 1920. aastatel veel kogu ühiskonda puudutavat mõju. Aktiivsemalt toimus ees- ja perekonnanimede eestistamine 1930. aastate keskel, kui möödus ühtlasi sada aastat perekonnanimede panekust (Must 2000: 62-63). Ka kohanimede eestistamisel olid 1920. aastad justkui ettevalmistus millekski suuremaks. Võib öelda, et nii inimeste nimede kui ka toponüümide eestistamine oli osa protsessist, millega toonitati eestlaste rahvuslust ja vajadust end lahti siduda nii saksa kui ka vene pärandist.

Vallad kui omavalitsusüksused on praeguseks pea kaks sajandit vanad ning nende ajalugu kannab endas ka osakest Eesti ajaloost. Valdade tööpõhimõtteid ning olemust on kujundanud kõik valitsenud võimud ning see kajastub ka vallanimedes. Valdade liitmine ja selle kaudu neile uute nimede andmine on praegugi päevakajaline teema. Käimasoleva riigi- ja haldusreformi tulemusena väheneb omavalitsuste üldarv Eestis oluliselt ning ühinenud omavalitsusüksuste nime- ja identiteediküsimus on terav.

Nimed võivad liita ja ühendada, aga samal määral ka tülli ajada. Lähiminevikust leiame konkreetse näite, kui 2008. aastal Halliste ja Abja vald olid ühinemislepingu koostamisel juba lõppfaasi jõudnud, kuid uuele vallale nime leidmine katkestas protsessi (Ernits 2009). Ühinemiskomisjonis otsustati uueks nimeks määrata Halliste kui vanem, ajaloolisem ja ühtlasi endise kihelkonna nimi. Sellist nimevalikut pooldas ka kohanimenõukogu kui seadusega määratud nõuandev organ. ${ }^{1}$ Abja kui jõukam vald soovis järeleandmatult säilitada oma nime ning lõppkokkuvõttes jäi ühine vald loomata. Käesoleva reformi senini suurim nimetüli on puhkenud Helme/Tõrva vallanime ümber. Üheltpoolt soovitakse säilitada Tõrva kui linnanime, teisalt pakutakse uuele vallale nimeks ajaloolist kihelkonnanime Helme. Laual on olnud ka variant Lõuna-Mulgi vald, kuid see on paljuski kasutusel juba Halliste, Abja ja Mõisaküla piirkonnas, kus näiteks ilmub ajaleht Lõuna-Mulgimaa. Irooniliselt on uue valla nimeks pakutud ka Mulkla (Starke 2016). ${ }^{2}$ Siinkohal võib tõmmata paralleeli 1930. aastatega, kui Kaiu ja Kuimetsa valla nimeprobleemi lahenduseks soovitas Tallinna linnaarhivaari abi ja Kohanimede Nõukogu liige Rudolf Kenkmaa nime Riiuvald (ERA, f 40, n 1, s 6019: 1 432-433).

${ }^{1}$ 2000. aastal on kohanimenõukogu välja andnud vallanimede valiku soovitused, mille järgi tuleks eelistada pika järjepideva traditsiooniga maa-alaliste üksuste, näiteks kihelkondade nimesid (Vallanimede... 2000; vt ka Päll 2016).

2 2016. aasta 21. juunil Tõrvas toimunud Helme valla, Hummuli valla, Põdrala valla ja Tõrva linna volikogude ühisistungil allkirjastati omavalitsuste ühinemisleping ja otsustati, et uue omavalitsuse nimeks saab Tõrva vald (seda pooldas neljast liitujast kolm). 
Käesolev uurimuslik ülevaade käsitleb Eesti valdade nimeprobleeme peamiselt 1930. aastate lõikes. See aeg oli Eesti Vabariigis märgilise tähendusega. Rahvusluse tõusuga kaasnenud nimede eestistamise protsess jätkus hoogsalt ka vabariigi teisel kümnendil ning vallanimede muutused kulmineerusid 1939. aastal jõustunud vallareformiga. Millised olid toonased probleemid ja kas meil on tänasel päeval nendest midagi õppida?

\section{Valdade ja vallanimede ajalugu}

Eesti valdade alguseks võib lugeda XIX sajandi haku talurahvaseadusi, mille järel hakati looma mõisakogukondade kaupa nn mõisavaldasid. Konkreetsema sisu valdadele andis 1856. aasta „Valla kogukonna seadus” ning 1866. aasta vallareformiga said juba talupojad ise endale vallavalitsust valida (Pae, Tammiksaar 2015: 15). Suurem osa Eesti valdadest saigi oma nime mõisa järgi, mille maadele ta asutati. XIX sajandi viimastel kümnenditel toimunud valdade liitmiste tulemusel said uued vallad endale enamasti ühe liitunud valla nime. Ammendavaid järeldusi, miks üks või teine vald endale just niisuguse nime sai, on täna raske teha. Tõenäoliselt mängis paljudel juhtudel rolli mõisa suurus ja tuntus.

Saaremaa näitel vaatame põhjalikumalt vallanime moodustusprintsiipi XIX sajandil. Enne 1890. aastate haldusreformi oli Saaremaal 112 valda (LVVA, f 6828, n 4, s 347: 1), millest valdade liitmisega jäi järele 19. Saaremaa oli Eesti teiste maakondadega võrreldes vaesem ja eripäraks oli suur kroonumõisate hulk. Võib öelda, et talurahvakomissar Jossif Kassatski eestvõttel 1890. aastatel toimunud ühendamiste käigus toimus vallareform, mis korrastas Saaremaa vallavõrgu niivõrd, et 1930. aastatel oli Saare maakonnas vaja teha vaid üksikuid pisimuutmisi (Pae, Tammiksaar 2015: 18). Ka valdade nimemuutused Saaremaad sisuliselt ei puudutanud (vt kaart 1). Saaremaa 112 vallast enamiku nimi lähtus mõisanimest, vaid mõnel juhul külanimest (näiteks Koguva ja Võhma) ning kahel juhul ka mõisata saare nimest (Ruhnu ja Kesselaid). Liitmiste tulemusel võeti enamasti kasutusele üks mõisanimedest, kuid erandina sai Kihelkonna vald nime just kihelkonna enda nimest. Kihelkonnanimest lähtuti ka Mustjala ja Kärla puhul, kuid ühtlasi oli kummalgi juhul olemas samanimeline mõis. Lisaks olid kõikides kihelkonnakeskustes kihelkonnanimedega kirikumõisad. Saaremaa vallanimesid mõjutas ilmselt ka õigeusu levik, sest mitu uut valda sai nime õigeusukiriku asukoha järgi (Pärsama, Leisi). Huvitavat juhtumit kujutab endast Abruka valla nimi. Algselt vaid Abruka saart hõlmanud väikevalla nimi laienes liitmiste käigus Saaremaale, hõlmates suuresti Anseküla kihelkonna territooriumi. Abruka valla nimi muudeti Salmeks 1936. aastal (ERA, f 40, n 1, s 5891: pg-ta).

Kuigi enamik vallanimesid pärines mõisalt, oli ka erandeid. Kose kihelkonna Nikolai, Vladimiri ja Aleksandri valla nimed olid 1890. aastate alguse vallareformijärgselt mõjutatud venestamisest (Kuda... 1891: 951; Эстляндскія... 1891). Aleksandri vald oli nimetatud konkreetselt tsaar Aleksander III järgi (Triiklane 1930). Võrumaa Aleksandri vald oli seevastu aga nimetatud Pragi mõisa saksakeelse nime järgi. Väiksed muutused venekeelsete vallanimede poole toimusid veel Esimese maailmasõja ajal, kui 1915. aastal nimetati Riisipere vald Sergejevi ja Prangli vald Ostrovskaja vallaks (Uuet 2002: 26). Lühikest aega (1916-1917) eksisteeris ka Mihaili vald Varbola ja Aleksei vald 
Kirna asemel. Enamik neist nimedest muudeti eestikeelseks pärast tsaaririigi kokkuvarisemist. Omaette teema on muidugi nime staatus ja keelsus. Kui näiteks muudeti Mihaili vald ametlikult Schwarzeniks (Михайловская > Швариенская; Эстляндскія... 1917), siis arvatavasti eesti keeles oli paralleelselt kasutusel ikkagi Vardi (Vaardi), mis oli eestikeelne mugandus Schwarzenist.

\section{Vallanimede muutmise ettevalmistav periood}

Et 1920. aastatel valdu massiliselt ei liidetud, ei olnud põhjust ka nimesid muuta, mitmed ettepanekud lükati tagasi või edasi põhjendusega varsti jõustuvast uuest seadusest. Vaid paberile jäi näiteks plaan rajada 1923. aastal Meeksi valla põhjaosast, Piirissaarest, Kastre-Peravallast, Pedaspää külast ja Emajõe suudmealast uus Järve vald (ERA, f 40, n 1, s 5874: 379-384). 1923. aasta detsembris on nimemuutust alustanud Võtikvere vald, viidates asjaolule, et Võtikvere jäi 1890. aastate reformis valla nimeks vaid seetõttu, et tegemist oli kroonuvallaga. Valla keskus oli Võtikverest $13 \mathrm{~km}$ eemal Tormas ja ka vallarahva suus räägiti enamasti Torma vallast (ERA, f 40, n 1, s 5874: 475-475p). Nimemuutus seadustatigi 1924. aasta alguses (RT 1924). Mainida võib veel 1926. aastal Pärnumaal asuva Seli valla nime muutmist Selisteks põhjusel, et ka Harjumaal asus sama nimega vald. Vald soovis esialgu uueks nimeks võtta Selli, nagu oli venekeelne variant senisest nimest, kuid Tartu Ülikooli professorite nõul sai uueks nimeks Seliste (ERA, f 1097, n 1, s 701, 1-11). Omaette teema oli Narva jõe taguste ja Setumaa valdade nimedega. Tartu rahulepingu sõlmimise järel moodustati iseseisev Petseri maakond, mis jagunes neljaks suureks vallaks: Irboska, Panikovitschi, Petseri ja Slobodka. Narva jõe taga moodustus kolm valda: Naroova (Narva), Kose ja Skarjatina (Uuet 2002: 33-34). Kuna Petserimaa oli suure rahvastikutihedusega, tekkis üsna pea praktiline vajadus suured vallad väiksemaks teha. 1922. aastal moodustati senise nelja valla asemele 11 uut valda: Irboska, Järvesuu, Kulje, Laura, Mikitamäe, Obinitsa, Pankjavitsa, Petseri, Satserinna, Senno ja Vilo. Neist Obinitsa muudeti Meremäeks ${ }^{3}$, Mikitamäe Mäeks ning Pankjavitsa Rootovaks juba 1923. aastal. Mitu nimemuudatust tehti Petserimaal veel ka 1939. aastal jõustunud reformiga.

Üks poleemikat põhjustanud nimemuutus toimus Harjumaal Kodasoo vallas. Nimelt soovis 1925 . aastal Kodasu vallanõukogu muuta valla nime Kodasooks, pidades u-ga nimekuju eksituseks Saksa okupatsiooni ajal. Omavalitsusasjade Talitus soovitas asja ikka lähemalt uurida ja pidada nõu Emakeele Seltsi ja eeskätt Mattias Johan Eiseniga. Maavalitsus on ministeeriumisse saatnudki kirja, et nii M. J. Eisen kui ka J. Jung tarvitavad oma teostes soovitavat nimevarianti, seega oleks nimemuutus igati õigustatud (ERA, f 40, n 1, s 6011: 206-214). Kuna nimemuutust peeti pigem keeleliseks, siis piisas teate avaldamisest Riigi Teatajas (RT 1925b). Kuna tegelikkuses polnud Emakeele Seltsiga nõu peetud, siis hiljem soovitab selts valla nime Kodasuuks tagasi muuta, kuid edutult (Võitlus... 1929).

${ }^{3}$ Obinitsa valla nimi muudeti ära põhjusel, et Obinitsa vallamaja asus Obinitsa külast 7-8 km eemal Mihailovo talus, aga inimesed otsisid vallamaja ikka Obinitsa külast. Nimeks valiti „terves Eestis tuntav Meremägi”, mille jalamile ehitati ka vallamaja (ERA, f 40, n 1, s 5999: 339-340). 
1928. aasta 29. juunil on kohtuministeerium saatnud vabariigi valitsusele kirja, kus väideti, et valdade nimede alal on tarvis selgust, kuna õigekirja osas valitseb sageli segadus. Teatud juhtudel oleks vaja ka vallanimed eestistada ning kuna omavalitsuste asjade korraldamine on siseministeeriumi ülesanne, siis peaks just siseministeerium olema selle eestvedaja. Kohtuministri ettepanek leiab valitsuse heakskiidu ja selle dokumendiga ongi määratud, et edaspidi tegeleb vallanimedega just siseministeerium (ERA, f 31, n 3, s 4041: 1-2). Seepeale saatis siseministeeriumi administratiivosakond kõigile maavalitsustele kirja koos Akadeemilise Emakeele Seltsi koostatud nimekirjaga (ERA, f 1097, n 1, s 894: 1-4p). Maavalitsustele tehti ülesandeks selgitada välja vallad, mille nimekasutus erineb nimekirjast, küsida arvamust asjassepuutuvatelt valdadelt ning teatada seejärel siseministeeriumile maavalitsuse teadmised ja arvamused kõigi valdade kohta. Et valdade reform eelnõust kaugemale ei jõudnud, ei muudetud ka ühegi valla nime ning protsess lükati kuni uue seaduseni edasi (ERA, f 40, n 1, s 5884: pg-ta). Teada on, et Pärnumaal toimetati siseministeeriumi kõigi ettekirjutuste kohaselt ning saadeti lõppkokkuvõte ka ministeeriumisse (ERA, f 1097, n 1, s 894: 10-12), kuid nimemuutmisi sellele ei järgnenud. Ainukese reaalse mõjuna vallanimede muutusele sellest perioodist võib tuua Moisekatsi valla Moosteks ümbernimetamise 1931. aastal (RT 1931). ${ }^{4}$ Nimemuutmine käiski läbi Riigi Teataja, kuid siinjuures oli üsna erinev, kes selle teatavaks tegi. Kui Kodasoo puhul oli selleks Harju maavalitsus, siis Mooste puhul oli tegemist kohtu- ja siseministri otsusega. Zooru valla nime muutmisel Tsooruks piisas aga vaid vallavalitsuse teatest, et 1925 . aasta 1. jaanuarist on valla nimi Tsooru ${ }^{5}$ (RT 1925a).

\section{Eesti Rahvusluse Ühing ja vallanimede eestistamine}

Uut vallareformi valmistati ette juba 1930. aastal, kuid kõige initsiatiivikamaks vallanimede eestistajaks osutus hoopis 1928. aastal loodud Eesti Rahvusluse Ühing (ERÜ). ${ }^{6}$ 1930. ja 1931. aastal saatis ERÜ maavalitsustele võorrapäraste vallanimede nimekirjad ning omapoolsed uute nimede soovitused, mille oli kokku pannud ühingu nimede eestistamise toimkond M. J. Eiseni juhti-

\footnotetext{
${ }^{4}$ Moisekatsi oli valla ametlik nimetus, kuid kuna kogu ümberkaudne rahvas oli ajast aega kasutanud nime Mooste, oli vald oma kulu ja kirjadega valmis nime vahetama. Uue seaduse jõustumist ei soovitud ootama jääda väga pragmaatilistel põhjustel, nimelt ametliku ja tegelikult kasutatava nime erinevusest tingituna oli tihti probleeme posti saatmisel ning kuna valla postitemplid olid väga kulunud, peeti mõistlikuks tellida uued juba õige ja pikaajalise nimega (ERA, f 40, n 1, s 5884: pg-ta)

${ }_{5}$ Tsooru valla nimi muudeti 1939. aastal jõustunud reformiga Lepistuks. Kohanimi Lepistu seostub peamiselt Lepistu kooliga (algselt Tsooru ministeeriumikool), millist nime hakati kasutama 1920. aastatel. Nimemuutuse taga oli vana nime halvakõlalisus (Saar 2016). Lepistu vald kaotati 1950. aastal ning kohanimi säilis jällegi vaid kooli nimes.

${ }^{6}$ Eesti Rahvusluse Ühing loodi eesmärgiga „edendada ja süvendada Eesti rahvustunnet ja teadvust ning arusaamist Eesti rahvusideoloogiast" (ERA, f 14, n 11, s 64: 3). Rahvusluse teemadel peeti kõnekoosolekuid, avaldati arvamust kõlbluse teemadel ning propageeriti kohanimede eestistamist. Ühingu algatusel tähistati mitmel aastal Tartus Jüriöö ülestõusu aastapäeva. Tuntumatest isikutest oli ühinguga seotud keelemees Johannes Aavik. Kirjasaatja, kes kirjutas alla ka kõigile maavalitsustele saadetud pöördumistele, oli René Ode. ERÜ aktiivsem tegevus lõppes 1933. aastal (ERA, fR-1252, n 1, s 23; Pae, Tammiksaar 2015: 29; J. A. 1928).
} 
misel. ${ }^{7}$ Peamiseks võõrapärasuse põhjuseks oli nime pärinemine endise mõisniku nimest, mis rahvusmeelsetele kodanikele ei sobinud. Olgugi et paljud nimed olid niivõrd mugandunud ja tundusid eestipärastena, siis „ei saa veel sellega ütelda, et need nimed oleksid täiesti omapärased ja meie oludes otstarbekohased ning sündsad” (ERA, f 3171, n 1, s 230: 5). „Nii mõnegi mõisniku nimi, mida vald kannab, on seotud raskete ja kurbade mälestustega Eesti rahvale" (ERA, f 4857, n 1, s 90: 40). Üldiselt soovitati valdadele valida mõni olemasolev nimi valla territooriumilt, näiteks küla, jõe või järve nimi. Võimaluse korral tegi ERÜ konkreetsemaid ettepanekuid. Kindlasti saatis ERÜ kirjad Valga (ERA, f 3171, n 1, s 230: 5-7), Viljandi (ERA, f 4857, n 1, s 90: 10-11), Viru (ERA, f 3138, n 1, s 694: 51-54) ja Pärnu (ERA, f 1097, n 1, s 1051: 1-2) maavalitsusele. Ajaleheartiklite järgi ka Harju (Harju... 1930) ja Järva (Võõrapäraste... 1930) maavalitsusele. ERÜ protokollides kajastub osaliselt ka tagasiside. Nii näiteks on Järva ja Viljandi maavalitsused saatnud ERÜ muutmisettepanekud edasi vallavolikogudele, kuid kõigist volikogudest on tulnud eitav vastus (ERA, f 3185, n 1, s 3: 8). Virumaa puhul aga on näiteks Voka vallavolikogu 25. juulil 1930 kümne poolt ja viie erapooletu häälega ERÜ ettepanekul võtnud valla nimena kasutusele Alutaguse (ERA, f 3185, n 1, s 3: 8-8p; ERA, f 3138, n 1, s 691: 16). Siiski on Viru maavalitsus selle otsuse tühistanud, põhjendades, et Alutaguse hõlmab tervet Virumaa idapoolset osa ja seetõttu pole õige ainult ühte valda sarnase nimega nimetada, lisades, et maavalitsusel poleks midagi selle vastu, kui valla nimi muudetakse Oruks või Pühajõeks (ERA, f 3138, n 1, s 646: 46). Mõni nimemuutus siiski 1930. aastate alul aset leidis, aga need olid pigem praktilist laadi ega lähtunud ERÜ ettepanekutest. Näiteks liitusid 1932. aastal Vana-Laitsna ja Rogosi vald ühtseks Laitsna-Rogosi vallaks (RT 1932). 1933. aastal Kioma ja Kähri valla ühinemisel jäi nimeks Kioma vald (RT 1933).

Kõik ERÜ tehtud 1930. aastate alguse muudatusettepanekud on toodud tabelis 1. Et vallareform jäi kinnitamata ka 1930. aastal, ei olnud ERÜ kirjadel selget mõju ning nendest ajendatuna ei muudetud ühegi valla nime. Võib öelda, et valdav enamik ERÜ pakutud variantidest ei läinud käiku ka hiljem, kuid nende jõuline suund nimede eestistamisele kandis kindlasti vilja.

Valdade nimeküsimusega sundisid tegelema ka puhtpraktilised põhjused. 1934. aastal koostas postivalitsus „Posti-, telegraafi-, telefoni- ja raadio-asutiste ning abiasutiste nimestiku", mida analüüsisid Akadeemilise Emakeele Seltsi ja Tartu Ülikooli geograafia kabineti esindajad (ERA, f 40, n 1, s 5890: pg-ta). Nimekirjas tulid hästi esile mitmed võõrapärase kasutusega vallanimed, postivalitsus oli postiasutuste nimedena kasutusele võtnud eestipärased ja rahva poolt kasutatavad nimed. Seevastu kasutasid mitmed vallad endiselt vanapäraseid ja võõrakujulisi nimesid. Nimestiku ja analüüsi põhjal saatis Akadeemiline Emakeele Selts siseministrile nimekirja 25 valla nimega, mis kindlasti muutmist vajaksid (vt tabelit 2). Kui ERÜ muudatusettepanekud olid seotud nimede sisulise tähendusega, siis Akadeemilise Emakeele Seltsi muudatused lähtusid puhtalt õigekirjareeglitest ning tõid kaasa enamasti paari tähe muutmise.

${ }^{7}$ ERÜ protokollidest nähtub, et 1928. aasta detsembris moodustati tänavanimede toimkond, mis töötas välja Tartu tänavanimede muutmise kava. Eelkõige tegeleti rajatava Tähtvere linnaosa tänavanimedega. Ilmselt seesama komisjon tegeles edaspidi ka vallanimedega. M. J. Eisen ise ERÜ-sse ei kuulunud (ERA, f 3185, n 1, s 3: 3p). 


\section{Eesti Rahvusluse Ühingu poolt 1930. ja 1931. aastal pakutud nimevariandid}

\begin{tabular}{|c|c|}
\hline Kehtiv nimi & Soovituslikud nimed \\
\hline Aaspere & Valgejõe, Võipere, Telliste, Auküla \\
\hline Anna & Eha, Koidu, Virve \\
\hline Einmani & Raja \\
\hline Enge & Salu, Uduvere, Mõnuvere, Eametsa, Korbe \\
\hline Esna-Orrisaar & Orisaar, Kareda \\
\hline Heimtali & Koduoru, Raudna \\
\hline Holdre & Ilmuse \\
\hline Holstre & Paistu, Nõmme \\
\hline Iisaku & Kuru, Terevere, Salliku, Alajõe, Roostaja, Alutaguse \\
\hline Kalvi & Ranna, Raudna, Laheküla, Meriküla \\
\hline Killingi & Kurgoja, Veski, Männiku, Kivilaane, Nõmme, Urajõe, Vaskjõe \\
\hline Leebiku & Lembitu, Õhne \\
\hline Loodi & Loo, Õisu \\
\hline Maidla & Virunurme, Tarumaa, Aidu, Uniküla, Aruvälja, Ojamaa, Hiiesoo \\
\hline Peetri & Sininõmme, Meriküla, Alutaguse \\
\hline Polli & Mägiste, Uriküla, Uillujõe, Lilleoja, Alatsjärve \\
\hline Porkuni & Aru, Tõnuvere, Nurmetu, Lasila, Valgejõe, Kalevi \\
\hline Pornuse & Kaubi, Halliste, Ereste, Hõbemäe \\
\hline Prangli & Laiu, Saare, Uhti \\
\hline Päri & Pärna, Raudna \\
\hline Riidaja & Alliku \\
\hline Saksi & Aruküla \\
\hline Skarjatina & Raja \\
\hline Taagepere & Vaguküla, Vaoküla \\
\hline Taali & Paistu, Tammiste, Tammaru, Oraste, Veske, Rütavere, Kurina \\
\hline Triigi & $\begin{array}{l}\text { Tammetsa, Nõmmeküla, Paunküla, Pala, Lindjärve, Kiravere, } \\
\text { Mustjärve }\end{array}$ \\
\hline Voka & Oru, Päite, Pühajõe, Alutaguse \\
\hline Voltveti & Metsa \\
\hline
\end{tabular}

Taaskord jõudsid nii valdade reform kui ka vallanimed arutluse alla 1935. aasta kevadel, kui geograafid Endel Krepp ja Johannes Maide alustasid haldusreformi eeltööd, mis kulmineerus haldusreformi teadusliku põhjenduse ja kavaga. 1936. aasta alguses pandi see plaan seoses keerulise sisepoliitilise olukorraga seisma ning sama kava teostus alles 1939. aastal (Pae, Tammiksaar 2015: 23-24). 
Akadeemilise Emakeele Seltsi 1935. ja 1938. aastal pakutud nimevariandid (ERA, f 14, n 2, s 440: 14; ERA, f 40, n 1, s 5890: pg-ta)

\begin{tabular}{l|l||l|l}
\hline Kehtiv nimi & $\begin{array}{l}\text { Soovituslik uus } \\
\text { nimi }\end{array}$ & Kehtiv nimi & $\begin{array}{l}\text { Soovituslik uus } \\
\text { nimi }\end{array}$ \\
\hline Einmanni* & Einmani, Vajangu & Nõmküla* & Nõmmküla \\
Emmaste* & Emaste & Paadermaa* & Paderma \\
Hallinga* & Halinga & Puurmani \\
Jõelehtme & Jõelähtme & Raiküla & Raikküla \\
Jõgisoo* & Jõgisuu & Rikholdi & Riguldi \\
Skarjatina & Karjati & Satserinna & Satseri \\
Kioma & Kiuma & Uue-Suislepi* & Uue-Suislepa \\
Kodasoo* & Kodasuu & Vana-Suislepi* & Vana-Suislepa \\
Kolovere & Koluvere & Vana-Tänasilma & Vana-Tänassilma \\
Kongota* & Konguta & Varbula \\
Kulje* & Kuulja & Varbola & Änge \\
Keina & Käina & Enge & \\
Laanemetsa & Lannametsa & Heimtali** & Tleksandri** \\
Lümmada* & Lümanda & Taagepere** & Taagepera \\
\hline
\end{tabular}

* vallanimi esines ainult 1935. aastal; ** vallanimi esines ainult 1938. aastal; tärnita - vallanimi esines mõlemas nimekirjas

Hoolimata sellest, et reform lükkus edasi ning ametlik, ülevalt alla koordineeritud nimemuutus teoks ei saanud, muutsid mitmed vallad siiski oma nime (1935. a Einmanni Vajanguks, Suuremõisa Pühalepaks, 1936. a Kogula Valjalaks ja Abruka Salmeks. 1937. a moodustati Uue- ja Vana-Suislepa vallast Suislepa vald). Lisaks nimemuutustele kadus valdu ka liitumiste teel (Uuet 2002: 54). Üheks huvitavaks erandjuhtumiks kujunes Meeksi vald, kus nimeküsimused enne 1939. aasta reformi ja selle ajal tuliseks kiskusid. 1937. aasta maikuus otsustas Meeksi vallavolikogu võõrapärasuse vältimiseks võtta uueks nimeks Mehikoorma. Akadeemiline Emakeele Selts nõustus valikuga ja leidis, et „Meeksi ei tarvitse olla võõrapärane [nimi], kuid keelelisest seisukohast [on] Mehikoorma igatahes ilmekam eestipärane nimi kui Meeksi" (ERA, f 40, n 1, s 6027: 85). Mehikoorma nimi polnud sugugi meeltmööda valla teistele suurtele küladele, nii et 1938. aasta mais hakati lausa allkirju koguma, et reformiga taastada valla endine nimi. Mehikoorma nimega kerkis selgelt esile ka rahvusküsimus, sest kohalikud eestlased arvasid, et „Mehikoorma on kiisa venelaste küla ning seepärast ei kõlba nimeks ühele ausale Eesti vallale [---] küla elanikud enamuselt olla riigivastased." Kohalike elanike vastuseis uuele nimele sai ametlikuks septembris toimunud koosolekul, kus valla organisatsioonide ja rahva esindajatest 20 Meeksi nime ja vaid üks Mehikoorma nime poolt hääletas (Pae, Tammiksaar 2015: 29-30). Rahva vastuseisust lähtudes sai Kohanimede Nõukogu soovitusel valla uueks nimeks Meeksi (ERA, f 40, 


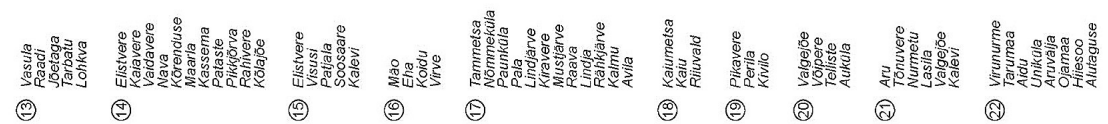

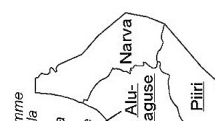

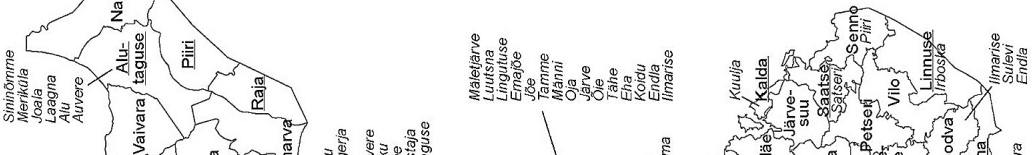

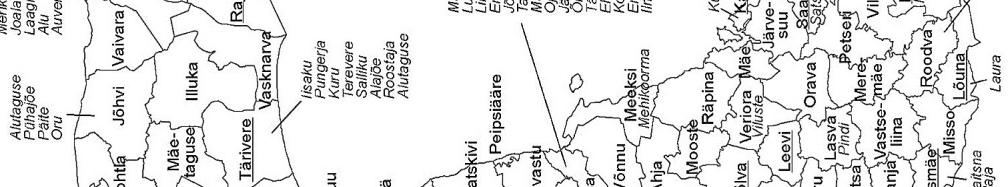

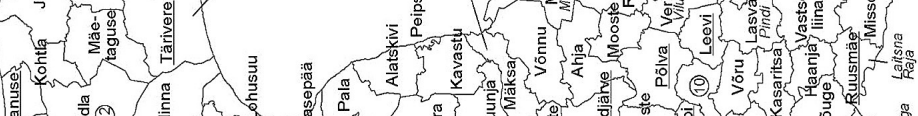

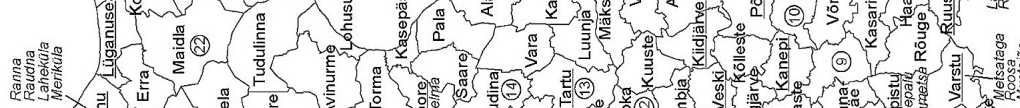

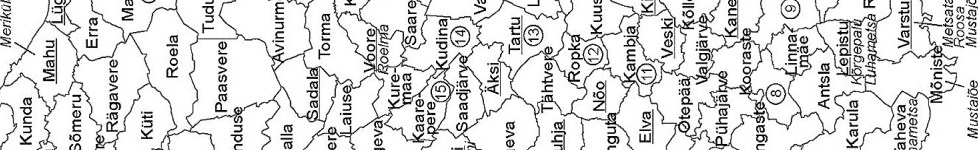
$\begin{cases}0 \\ 0\end{cases}$

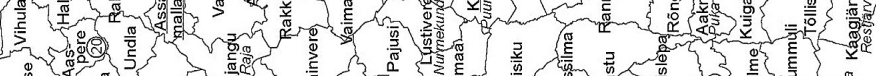
20. (1)

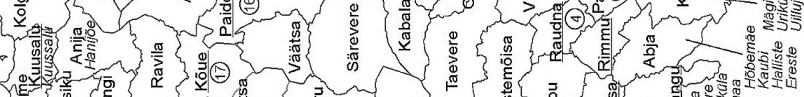

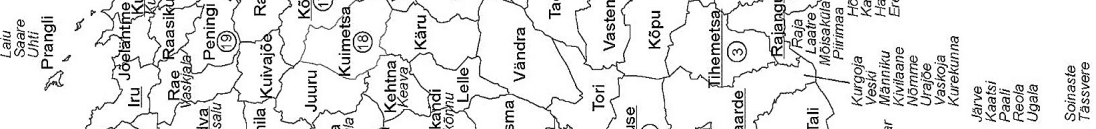

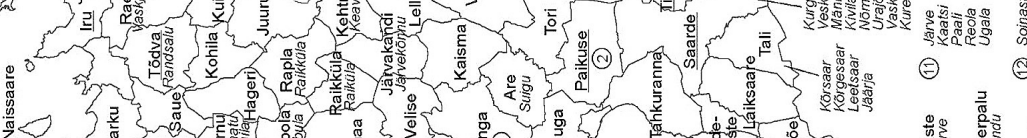

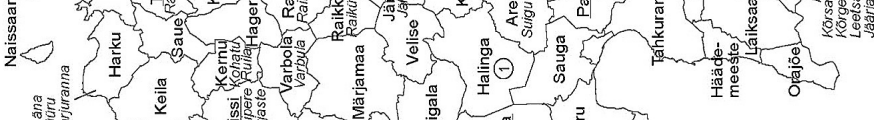
要至

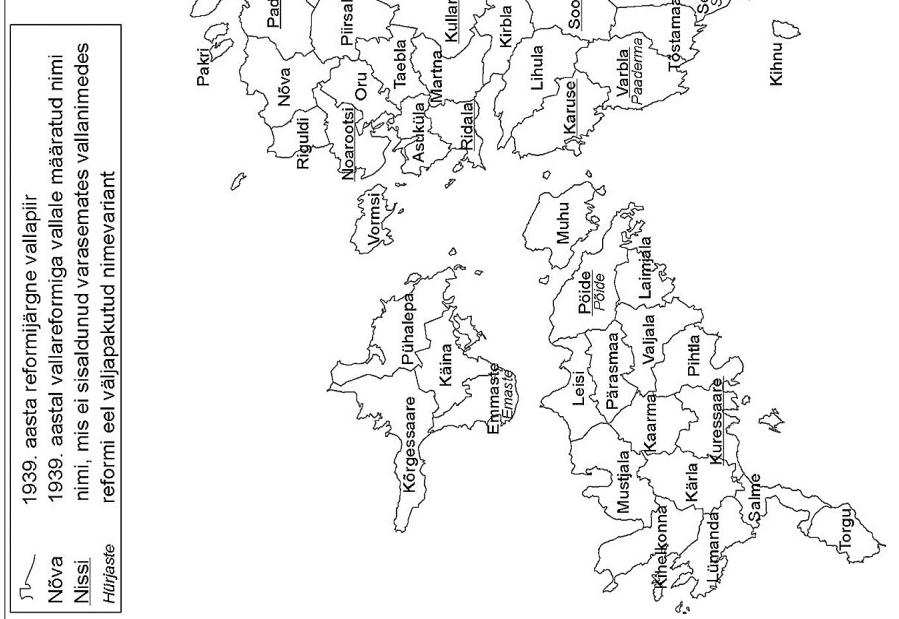

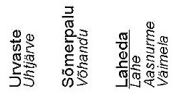
()) $(\odot)$

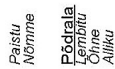
()) $\odot$

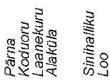


n 1, s 6019: 369p), kuigi ERÜ Meeksi nime võõrapäraseks ja mõisniku nimest tuletatuks pidas (ERA, f 14, n 2, s 440: 17p). Mehikoorma vald sai nimena eksisteerida vaid poolteist aastat.

\section{Valdade reform 1939. aastal ning vallanimede kinnitamine}

Suurim nimede muutmine toimus 1938. aastal, kui pandi kokku reformikava, mis jõuti ka kinnitada. Vallanimede muutmise aluseks sai 19. aprillil 1938 riigihoidja dekreedina välja antud koha- ja kinnistusüksuste nimede korraldamise seadus (RT 1938a). Seaduse kohaselt pidid kõik haldusüksused ja asulad kandma eestipäraseid nimesid ning senini kasutuses olevad võõrapärased, labase tähenduse või halva kõlaga nimed kuulusid muutmisele. Seadusest tulenevalt palus siseministeerium Akadeemilise Emakeele Seltsi hinnangut võõrapäraste vallanimede kohta. Seltsi vastusena esitatud nimekiri, milles olid peale küsitud võõrapäraste nimede ka keeleliselt valesti kasutatavad nimed, kattus suurel osal 1935. aastal ministeeriumile saadetuga (vt tabelit 2). Muutmist vajavate nimedena olid seal võõrapärased vallanimed Heimtali ja Aleksandri ning vigane Taagepere, mille asemel soovitas selts kasutada Taagepera nime (ERA, f 14, n 2, s 440: 13-16).

Koha- ja kinnistusüksuste nimede korraldamise seadusega loodi siseministeeriumi juurde nõuandva organina Kohanimede Nõukogu (RT 1938a). Kuid veel enne, kui nõukogu sai tööle asuda, kutsus siseminister 31. augustil kokku nõupidamise, kus olid esindajad Akadeemilisest Emakeele Seltsist, Akadeemilisest Ajaloo Seltsist, Eesti Maaomavalitsuste Liidust ning majandusgeograafiliste küsimuste eksperdina geograaf Endel Krepp, kes oli ka haldusreformi peamine väljatöötaja. Nõupidamisel kujundati omapoolne hinnang Eesti vallanimede eestistamise ja parandamise suhtes ning edastati see Kohanimede Nõukogule lõpliku seisukoha kujundamiseks (ERA, f 40, n 1, s 6019: 376). Kohanimede Nõukogu pidas oma esimese koosoleku 7. septembril 1938 ning andis hinnangu kõigile Eesti linnade, valdade ja maakondade nimedele (ERA, f 40, n 1, s 6019: 365-375p). Toimunu leidis laialdast kajastust ka kõigis Eesti tolleaegsetes suuremates lehtedes (Linnad... 1938; Eesti... 1938), LõunaPärnumaa vallanimede osas võttis ajalehes Uus Eesti sõna Saarde kihelkonna juurtega juuraprofessor Leo Leesment (1938). 7. oktoobril võttis president Konstantin Päts vastu otsuse nr 88 (RT 1938b), mille alusel hakkasid valdade uued piirid ja nimed kehtima 1939. aasta 1. aprillist.

Võrreldes Kohanimede Nõukogu protokolli ning presidendi poolt 7. oktoobril kinnitatud nimekirja, leiab sealt nii mõnegi erinevuse. Kohanimede Nõukogu leidis Petserimaal asuvate Irboska ja Laura valla nimed igati asjakohased olevat ning ajaloolistel põhjustel säilitamist väärt. Presidendi kinnitatud nimekirjaga nimetati vallad aga ümber, vastavalt Linnuse ja Lõuna vallaks. Leiab ka juhtumeid, kus nõukogu soovitas vallavalitsuse või maavalitsuse esialgse soovi asemel uut nime, kuid lõpuks valiti kolmas nimi. Näiteks sooviti Virumaal panna valla nimeks Pungerja, mida Kohanimede Nõukogu küla kauguse tõttu keskusest heaks ei kiitnud (ERA, f 40, n 1, s 6019: 371p). Pungerja asemel soovitas nõukogu hoopis Iisakut kui ajaloolise kihelkonna ja endise valla nime. Valla nimeks sai aga Tärivere, mille valikut põhjendas Uudisleht samanimelise koha põlise päritoluga (Uued... 1938). 
lisakut peeti liigselt võõrapäraseks ning uueks nimeks võeti piirkonna kõige vanem teadaolev nimi.

Võrumaal soovitas Kohanimede Nõukogu Raja asemele nime Laitsna ning Roosa vallale nime Metsataga, kuid presidendi otsusega kinnitati Laitsna asemel Ruusmäe ja Metsataga asemel Varstu. Huviväärne on Põdrala valla juhtum. Põdrala vald tekkis mitmest endisest väikevallast, peamisteks moodustajateks olid Riidaja, Leebiku ja Lõve. Nõukogu protokollides pole arutatud ei Põdrala ega ühegi endise väikevalla nime, kuid presidendi otsuses seisab uue valla nimena just Põdrala. Asja teeb veelgi huvitavamaks see, et ei arhiivimaterjalides ega ka ajalehtedes nime sünniloo kohta teavet ei leidu. ${ }^{8}$ Uue eestiliku nimena tuleb reformiga käibele ka Tihemetsa nimi. Peamiselt võõrapärase nimega Voltveti valla aladele tekkinud vallale otsiti nime just ajaloost, oletades, et Voltveti mõisa saksakeelne nimi Tigintiz on algupäraselt eesti nimi. Eelnimetatud 31. augusti koosolekul on mainitud, et Akadeemiline Emakeele Selts on ajaloolisest nimest Tignitz või Ticonas kujundanud soovitava nimena Tihekõnnu. Hiljem on see maha tõmmatud ja asendatud Tihemetsaga (ERA, f 14, n 2, s 442: 3). Kohanimede Nõukogu esimesel koosolekul on vallanimena mainitud juba Tihemetsat, mille nõukogu tuletas Tihekõnnust (ERA, f 14, n 2, s 442: 26p). Leesment (1938) on nime algupära seostanud nimedega Tihnise, Tihniku või ka Tihniste, neist viimast soovitas ta ka vallanimeks.

Reformi käigus vahetati tagasi Prangli valla nimi. Nimelt muutis Prangli vald Harjumaal 1926. aastal oma nime Pranglisaarte vallaks, sest nii oli see juba tsaariajal, rahvas kasutas sellist nime ning vabariigi algusajast olid ka templid Pranglisaarte nimega (ERA, f 40, n 1, s 5878: 384-393). Nimevahetust põhjendati asjaoluga, et sageli saadeti kirju valesti Vana-Prangli valda Tartumaal ning seetõttu võttis info õigesse kohta jõudmine tavapärasest rohkem aega. 1938. aastal aga soovitas Kohanimede Nõukogu nime tagasi Prangliks muuta, sest Pranglisaarte valla nimi oli liiga pikk (ERA, f 40, n 1, s 6019: 366p).

Nimekordustest tulenevalt muudeti vallanimesid mujalgi. Näiteks saadeti Roela valdade (Tartu-ja Virumaal) näitel igas kuus keskmiselt 5-6 kirja valesse valda (ERA, f 40, n 1, s 5893: 202-205). Siseministeerium ning virumaalased pooldasid varianti jätta Virumaa Roela endise nimega ning Viru-Roela postiagentuur nimetada ümber Roelaks, sest Virumaa Roela on ajalooliselt vanem kui Tartumaa Roela. Vältimaks kattuvaid nimesid tehti ettepanek muuta Tartumaa Roela Voore vallaks ning sealne postiasutus Voore postiagentuuriks. ${ }^{9}$ Viimane aga tekitas probleemi, sest Lõuna-Tartumaal oli juba olemas Voore-nimeline postiagentuur. Lõpplahendusena nimetati Lõuna-Tartumaa

${ }^{8}$ Põdrala nimi võeti käibesse 1939. aastal jõustunud vallareformi käigus vanemate kirjapanekute põhjal. Vald moodustati 1939. a Leebiku ja Riidaja vallast ning Helme, Jõgeveste, Kärstna, Lõve, Patküla ja Suislepa valla osadest. Vald eksisteeris aastatel 1939-1950 ning likvideeriti Tõrva rajooni loomisega. Aastast 1954 oli rajoonis Riidaja külanõukogu, mis nimetati Põdralaks 1990. a, vallaks sai ta 1991. a. Nime peetakse algselt külanimeks, vanemas riimkroonikas on 1223. a kirjas Podereial/Poderiale. Nimi on edasi elanud Riidaja mõisa nimes (Morsel Podrigel). Nime algkujuna on Marja Kallasmaa (2016: 511) oletanud Põderjala, mis võiks lähtuda isikunimest. Podereialist Põdralaks muutumist võib pidada rahvusromantiliseks keerdkäiguks Eesti toponüümikas.

${ }^{9}$ Kohanime Voore pakkus välja koolmeister August-Erik Arold (Ivar Aroldi suuline teade, 27. VI 2016; vt ka Lepiksoo 2007). 
Voore postiagentuur Talvikeseks ning kumbki Roela vastavalt esialgsetele plaanidele (ERA, f 14, n 2, s 440: 79-84).

Reformi käigus nimede muutmise ja eestistamise tähe all juhtus ka seda, et kaks või kolm valda tahtsid võtta sama nime. Nendel juhtudel tuli Kohanimede Nõukogul võtta selge seisukoht, millist nime kellelegi soovitada ja määrata. Nii juhtus kolme piiriäärse vallaga, kes kõik tahtsid uueks nimeks võtta Raja. Reformi tulemusel ja nõukogu soovitusel sai Virumaal asuv endine Skarjatina vald nimeks soovitud Raja, Võrumaa endine Laitsna-Rogosi vald uudisnimena Ruusmäe ning Pärnumaal mitmest vallast liidetud uus vald nimeks Rajangu. Sarnaselt tuli lahendada ka Virumaa ja Petserimaa valdade soov Piiri nimele (ERA, f 40, n 1, s 6019: 365-375).

\section{Pärast reformi}

Juba 1938. aasta 20. oktoobril saatis siseministeeriumile kirja Eesti Rahvusluse Ühing, kes oli eestipäraste nimede eest seisnud ka 1930. aastate alguses ning enne reformi maavalitsustega uuesti ühendust võtnud. Kuna kõiki nendepoolseid vallanimede muudatusi ei oldud kuulda võetud, saadeti kiri kaheksa nimemuudatusega otse ministeeriumisse (ERA, f 14, n 2, s 440: 17-18). ${ }^{10}$ ERÜ põhjendas oma nõudmisi sellega, et kui tol hetkel jäävad nimed muutmata, tuleb selleks vajadus mõne või mõnekümne aasta pärast, nii et otstarbekam on nimed kõik koos ära muuta. Kui ministeeriumis ühingu arvamust kuulda ei võetavat, lubati kirjutada igale vallale eraldi vallanime kõlbmatuse kohta. ERÜ järjekindluse ja sõnadest kinnipidamise kohta annab kinnitust Mäksa vallale saadetud kiri, millest ajendatuna oli vallal 1938. aasta lõpus soov nime muuta. Uueks nimeks valitud Emajõe vald jäi siseministeeriumis aga selle sobimatuse ja põhjendamatuse pärast kinnitamata (ERA, f 14, n 2, s 440: 17-18, 222-225).

Pärast vallareformi jõustumist olid rahulolematud ka mitmed vallad ning vallakodanikud. Veel enne kui reform 1. aprillil jõustuda jõudis, soovis veebruaris Taali vallavolikogu muuta Paikuse valla nime Pärnjõe vallaks. Vastavasisuline taotlus saadeti siseministrile, kes lükkas selle tagasi põhjendusega, et nime peaks muutma uue valla vastavad organid. Nimelt 1939. aasta 1. aprillist toimunud reform toimus ilma kohalike omavalitsuste valimiseta. Esialgu määrati nn talitusvallad ning uued vallavolikogu valimised olid alles sügisel 1939. Sama sisuga vastuse sai ka Kuksema vallast pärit Villem Hein, kes saatis siseministrile omapoolse põhjenduse, miks ühinenud Kuksema ja Võhmuta valla uueks nimeks ei tohiks saada Võhmuta (ERA, f 40, n 1, s 5893: 200-201, 206-207). Siiski toimus pärast reformi ka üks vallanime muutus: Tärivere muudeti kohaliku rahva soovil tagasi Iisakuks, sest Tärivere oli vaid väike küla, kuid tõeliseks keskuseks oli vallas juba harjumuste kohaselt kujunenud Iisaku (Tärivere... 1940). 1939. aasta lõpus on siseministeerium vallavolikogu esitatud taotluse küll tagasi lükanud (ERA, f 2003, n 1, s 448: 13), kuid 7. mai 1940 Riigi Teatajas (RTL 1940) on Iisaku valla nimi taaskinnitatud. Seega eksisteeris Tärivere vald vaid ühe aasta.

\footnotetext{
${ }^{10}$ Kaarepere, Kambja, Kudina, Meeksi, Mäksa, Petseri, Roodova, Ropka.
} 


\section{Kokkuvõte}

Omavalitsusüksuste teatava poliitilise tausta tõttu on valdade nimed kuulunud valitseva võimu huviorbiiti eri aegadel. Uurides Eesti 1930. aastate vallanimesid, tulid välja selged jooned nimede määramise protsessis. Rahvusluse küsimus oli värskes vabariigis eriti päevakohane ning nii sai nimemuutmise kõige olulisemaks teguriks eestistamine. Minevikust ajendatuna kaotati nimedest seosed baltisaksa mõisnikega, asemele valiti ajaloolised või rahvusromantilised eesti nimed. Teine ja mitte vähem tähtis tegur oli nimede kasutamisest lähtuv praktiline väärtus. Et asjaajamine oleks lihtne ja kiire, pidi iga vald saama ainulaadse nime, mis ei korduks ega samastuks mõne vallanimega teises maakonnas.

1939. aastal läbiviidud valdade reformi tulemusel tekkinud 248 vallast said 52 endale täiesti uue nime ehk sellise, mis ei sisaldunud ega olnud tuletatud ühinenud valdade nimedest. Neist 16 valda nimetati kunagise kihelkonna järgi, mille Kohanimede Nõukogu tunnistas ajaloolise nimena vastuvõetavaks.

Vallanimede muutmise protsessi tähtsaimate osaliste ehk siseministeeriumi ning maa- ja vallavalitsuste kõrval mängisid olulist rolli ka Akadeemiline Emakeele Selts, Eesti Rahvusluse Ühing ning Kohanimede Nõukogu. Et nõukogu töötas seaduslikult määratud alusel, oli nende sõnajõud suurem kui ERÜ-l ja Akadeemilisel Emakeele Seltsil ning lõplikus otsustusprotsessis määravaim.

Uurimistöö tulemusena valminud kaardil 1 paistab, et nimevariante pakuti valdadele välja üsna palju. Tõmmates võrdlusmomente tänapäevaga, siis tundub, et vallanimede küsimus kõnetas toonases ühiskonnas rohkemaid. Siiski näitab hiljuti moodustatud Lääne-Saare valla nimekonkursile saabunud poolsada nime (Vinni 2014), et inimesed pole ükskõiksed ning võib ennustada, et nimevaidlused alles tõstatuvad.

Artikkel on valminud uurimisprogrammide IUT2-16 „Globaalne soojenemine ja maastike aineringe. Maastike struktuuri ja funktsioonide muutused seoses globaalse kliima soojenemise ja inimtegevusega ning aineringe modelleerimine ja ökotehnoloogiline reguleerimine” ja IUT2-17 „Rahvastiku ruumiline mobiilsus ja linnaregioonide areng" toel.

\section{Arhiivimaterjalid}

ERA, f 14, n 2, s 440. Kirjavahetus Kohanimede Nõukogu koosseisu ja tegevuse asjus.

ERA, f 14, n 2, s 442. Kohanimede Nõukogu koosolekute protokollid.

ERA, f 14, n 11, s 64. Eesti Rahvusluse Ühing.

ERA, f 31, n 3, s 4041. Vabariigi Valitsuse otsus vallanimede eestistamise kohta.

ERA, f 40, n 1, s 5874. Kirjavahetus maakondade ja valdade piiride, nimede ja vallavalitsuste asupaikade muutmise küsimustes.

ERA, f 40, n 1, s 5878. Kirjavahetus maakondade ja valdade piiride, valdade nimede ja vallavalitsuste asupaikade muudatuste ning suuremate alevite linnadeks muutmise küsimustes.

ERA, f 40, n 1, s 5884. Kirjavahetus maakondade ja valdade piiride, valdade 
nimede ning vallavalitsuste asupaikade muudatuste, alevikkude ja raudteejaamade piirkondade kindlaksmääramise küsimustes.

ERA, f 40, n 1, s 5890. Kirjavahetus maakondade, valdade, alevike, raudteejaamade piiride, külade nimede ja vallavalitsuste asupaikade muudatuste küsimustes.

ERA, f 40, n 1, s 5891. Kirjavahetus maakondade, valdade, alevike, raudteejaamade piiride, valdade nimede ja vallavalitsuste asupaikade muutmise küsimustes.

ERA, f 40, n 1, s 5893. Kirjavahetus maakondade, valdade, alevike ja raudteejaamade piiride, valdade nimede ning vallavalitsuste asupaikade muudatuste küsimustes. Viru maakonna ja Kiviõli kaardid.

ERA, f 40, n 1, s 5999. Kirjavahetus valdade piiride, nimede ja vallavalitsuste asupaikade muutmise küsimustes.

ERA, f 40, n 1, s 6011. Kirjavahetus valdade piiride, nimede ja vallavalitsuste asupaikade muutmise küsimustes.

ERA, f 40, n 1, s 6019. Kirjavahetus valdade reformide läbiviimise küsimuses.

ERA, f 40, n 1, s 6027. Toimik Tartumaa II valdade reformi kohta.

ERA, f 1097, n 1, s 701. Toimik Seli valla nime muutmise kohta.

ERA, f 1097, n 1, s 894. Toimik Pärnumaa valdade nimede õigekirjutuse selgitamise kohta.

ERA, f 1097, n 1, s 1051. Kirjavahetus Eesti Rahvusluse Ühinguga vallanimede eestistamise asjus.

ERA, f R-1252, n 1, s 23. Eesti Rahvusluse Ühing.

ERA, f 2003, n 1, s 448. Viru Maavalitsuse ringkirjad. Kirjavahetus perekonnanimede muutmise ja Tärivere vallale tema endise nime „Iisaku” tagasiandmise taotlemise kohta. Nime muutnud kinnistusüksuste nimekirjad.

ERA, f 3171, n 1, s 230. Kirjavahetus omavalitsusüksuste piiride muutmise küsimuses. Eesti Rahvusluse Ühingu ettepanek vallanimede muutmise kohta.

ERA, f 3138, n 1, s 646. Maavalitsuse koosolekute protokollid.

ERA, f 3138, n 1, s 691. Voka vallavalitsus.

ERA, f 3138, n 1, s 694. Kirjavahetus vallaomavalitsuste seaduseelnõu, sundmääruste kehtestamise, valdade nimede muutmise jt küsimustes. Kaitseliidu Kallivere rühma juhatuse valimiseelne üleskutse.

ERA, f 3185, n 1, s 3. [ERÜ] juhatuse koosolekute protokollid.

ERA, f 4857, n 1, s 90. Valla eelarved-aruanded ning siseministeeriumi, maavalitsuse jt ringkirjad ning kirjad vallakohtute valimise, Viljandimaa valdade nimede päritolu ja muutmise, järelevalve ja muis asjus.

LVVA, f 6828, n 4, s 347. Схематический плань границ соединенныхь волостей Эзельскаго уъзда Лифляндской губернии, 1896.

\section{Kirjandus}

Eesti kohanimeraamat. Toim Peeter Päll, Marja Kallasmaa. Tallinn: Eesti Keele Sihtasutus, 2016.

Eesti vallal olgu Eesti nimi. - Uus Eesti 13. IX 1938, lk 3.

Eestlasele eesti nimi. Akadeemilise Emakeele Seltsi toimetused II. Tartu, 1921.

Ernits, Peeter 2009. Abja mulgid ei taha Halliste nime. - Maaleht 22. I. http://maaleht.delfi.ee/news/maaleht/uudised/abja-mulgid-ei-taha-hallistenime?id=23964803 (14. VI 2016).

Harju valdadele eesti nimed. - Postimees 5. VII 1930, lk 6. 
J. A. [Johannes Aavik] 1928. Rahvustunde tähtsus. Eesti Rahvusluse ühingu puhul. - Postimees 5. XI, lk 7.

Kall a s ma a, Marja 2016. Põdrala. - Eesti kohanimeraamat. Toim Peeter Päll, Marja Kallasmaa. Tallinn: Eesti Keele Sihtasutus, lk 511.

Kuda Mosk. Vedomostile Peterburist telegrafeeritakse... - Olevik 25. XI 1891.

L e e s m e n t, Leo 1938. Uute valdade nimetused olgu eestipärased. - Uus Eesti 4. IX.

Le piks o o, Evi 2007. August-Erik Arold, koolmeistrist rahvavalgustaja - 125. Saare Valla Teataja 10. III, lk 4.

Linnad ja vallad ümberristimise tules. - Päevaleht 13. IX 1938, lk 4.

Mus t, Aadu 2000. Eestlaste perekonnaloo allikad. Tartu: Kleio.

P a e, Taavi, T a m miks a a r, Erki 2015. „See on ülesanne, mis mõtlevate inimeste üle jõu on käinud.” Valdade liitmise reformid Eestis. - Tuna, nr 4, lk 14-32.

Päll, Peeter 2016. Ütle üks ilus vallanimi. Õpetus algajatele vaderitele. - Postimees 21. IV. http://arvamus.postimees.ee/3663167/peeter-pall-utle-uks-ilusvallanimi-opetusi-algajatele-vaderitele (14. VI 2016).

RT 1924 = Siseministri poolt 26. jaanuaril 1924 a. vastuwõetud Võtikvere valla Torma vallaks nimetamise otsus. - Riigi Teataja, nr 20/21, lk 237.

RT 1925a = Tsooru vallavalitsuse teadanne. - Riigi Teataja, nr 9/10, lk 68.

RT $1925 b$ = Harju maakonnavalitsuse teadaanne. - Riigi Teataja, nr 199/200, lk 1160.

RT 1931 = Kohtu- ja siseministri 7. juuli 1931 otsus Moisekatsi valla Mooste vallaks nimetamise asjus. - Riigi Teataja, nr 56, art 449, lk 836.

RT 1932 = Kohtu- ja siseministri 17. juuni 1932 otsus Vana-Laitsna ja Rogosi valdade ühendamise asjas. - Riigi Teataja, nr 51, art 452, lk 678.

RT 1933 = Kohtu- ja siseministri 30. novembri 1933 otsus Kioma ja Kähri valdade ühendamise asjas. - Riigi Teataja, nr 99, art 712, lk 1154.

RT $1938 \mathrm{a}=$ Koha- ja kinnistusüksuste nimede korraldamise seadus. - Riigi Teataja, nr 42, art 397, lk 1450-1455.

RT 1938b = Vabariigi Presidendi otsus nr. 88. - Riigi Teataja, nr 87, art 776, lk 2099-2130.

RTL 1940 = Siseministri otsus 29. aprillist 1940 Tärivere valla nime muutmise kohta. - Riigi Teataja Lisa, nr 41, lk 1367.

Sa ar, Evar 2016. Tsooru. - Eesti kohanimeraamat. Toim Peeter Päll, Marja Kallasmaa. Tallinn: Eesti Keele Sihtasutus, lk 678.

Starke, Toomas 2016. Helme, Lõuna-Mulgi, Tõrva või hoopis Mulkla vald? Valgamaalane 18. III. http://valgamaalane.postimees.ee/3623457/arvamushelme-louna-mulgi-torva-voi-hoopis-mulkla-vald (14. VI 2016).

Triiklane 1930. Triigi vald ei taha olla Triigi. - Postimees 20. IX, lk 6.

Tärivere vald nimetati uuesti Iisakuks. - Virumaa Teataja 8. V 1940, lk 5.

Uued vallad sündinud. - Uudisleht 10. X 1938, lk 3.

Uuet, Liivi 2002. Eesti haldusjaotus 20. sajandil. Tallinn: Eesti Omavalitsusliitude Ühendus, Riigiarhiiv.

Vallanimede valiku soovitusi 19. VII 2000. http://www.eki.ee/knn/knn_vald.htm (15. VI 2016).

V in n i, Raul 2014. Uuele vallale pakuti 50 nime. - Saarte Hääl 3. IV. http://www. saartehaal.ee/2014/04/03/uuele-vallale-pakuti-50-nime/ (14. VI 2016).

Võitlus Kodasoo walla nime pärast. - Kaja 17. IV 1929, lk 6.

Võõrapäraste nimedega Järvamaa vallad. - Postimees 2. IV 1930, lk 6.

Эстляндскія губернскія вьдомости 21. XI 1891, lk 248.

Эстляндскія губернскія вђдомости 29. VI 1917, lk 110. 


\section{The question of municipality names in the Estonian municipality reform of the 1930s}

Keywords: municipality names, municipality reform, Estonianisation of names

By changing place names, authorities have always had the chance to impose their ideology. Therefore, every power changed those names in their own way - some of them more extensively, some just slightly. The aim of this study was to find out which were the main aspects of changing municipality names in the 1930s and who had the most impact on the process that was especially related to the municipality reform finalised in 1939. The study is based on archive materials from the Estonian National Archives. Some additional information was found from newspapers and legal texts of that time.

The main idea that dominated the name-changing process in the 1930 s was the Estonianisation of place names. A lot of municipality names used at the beginning of the $20^{\text {th }}$ century had originated from the names of Baltic German manor owners. After Estonia had gained independence in 1918, these names were found to sound foreign and thus unsuitable for a newborn nation-state. In addition to the general idea of Estonianising place names, there were other factors behind the namechanging process. The main reason was the municipality reform itself. During that time, the size of Estonian municipalities varied significantly and the smaller ones were often incapable of accomplishing the usual duties of local governments. During the municipality reform, over a hundred of smaller municipalities were merged into bigger ones. Every new municipality needed a name. Another reason stemmed from practicalities. There were many places in Estonia that had the same or a similar name, which caused frequent delays in post delivery as well as complications in other processes.

The process of changing the names of municipalities in the framework of the municipality reform was actually quite slow, taking over a decade due to many participants and political difficulties. Local and county governments, the national government, academic institutions, and voluntary activists were involved in the process. Each municipality was given an official name at the latest by 1939, when the municipality reform finally came to an end.

Taavi Pae (b. 1976), PhD, University of Tartu, Department of Geography, Research Fellow in Human Geography, taavi.pae@ut.ee

Madli-Johanna Maidla (b. 1994), University of Tartu, Master Student in Geography, madlijmaidla@gmail.com

Erki Tammiksaar (b. 1969), PhD, University of Tartu, Department of Geography, Senior Research Fellow in History of Geography, erki.tammiksaar@ut.ee 